\title{
MomentDergi
}

Hacettepe Üniversitesi İletişim Fakültesi Kültürel Çalışmalar Dergisi

2019, 6(1): 150-175

ISSN: 2148-970X.

Makaleler

\section{TÜRKIYE'DE LISANS DÜZEYINDEKI YENI MEDYA EĞiTiMi VE SEKTÖR BEKLENTiLERi ÜZERINE BİR DEĞERLENDIRME}

\section{Zeynep Özarslan*}

Öz

$\mathrm{Bu}$ çalışma, Türkiye'deki üniversitelerde lisans düzeyinde yeni medya eğitimi veren kurumlardaki müfredatlarda yer alan tüm zorunlu ve seçmeli dersleri sınıflandırmayı ve yükseköğretimdeki genel eğilimlerin niceliksel olarak değerlendirilmesini hedeflemektedir. Yaratıcı endüstrilerin bir parçası olarak kabul edilen dijital/yeni medya alanında, yükseköğretimdeki bu eğilimlerin sektördeki eğilimlerle ne kadar örtüştüğünü belirli bir açıdan ortaya koyabilmek amacıyla, sektördeki iş ilanları da incelenmiştir. Bu çalışma kapsamında iş ilanları, sektör beklentilerinin göstergelerinden biri olarak değerlendirilmiştir. Araştırmada doküman inceleme ve içerik analizi teknikleri birlikte kullanılmıştır. Araştırma sonucunda, dijital medya alanında istihdam edilmek üzere bireyler yetiştirme iddiasında olan belirli yükseköğretim kurumlarının müfredat geliştirme çalışmaları yaparken, sektörün beklentilerini de dikkate almalarının faydalı olacağı bulunmuştur. Ayrıca bir başlangıç olma iddiasındaki bu nicel çalışmaya ek olarak, ileride, yükseköğretimdeki ve sektördeki genel eğilimlerin daha ayrıntılı analizini sunmak için tüm paydaşlarla derinlemesine görüşme, anket gibi farklı teknikler kullanılarak nitel araştırmalar yapılmasının da gerekli olacağına inanılmaktadır.

\section{Anahtar Terimler}

yeni medya eğitimi, yükseköğretim, müfredat, yaratıcı endüstriler, dijital medya

* Doç. Dr. Zeynep Özarslan, İstanbul Rumeli Üniversitesi, Sanat ve Tasarım Fakültesi, Radyo, Televizyon ve Sinema Bölümü.

ORCID ID: 0000-0001-8278-3237, zeynep.ozarslan@gmail.com Makalenin Geliş Tarihi: 01/02/2019 Makalenin Kabul Tarihi: 11/06/2019

(c) Yazar(lar) (veya ilgili kurum(lar)) 2019. Atıf lisansı (CC BY-NC 3.0) çerçevesinde yeniden kullanılabilir. Ticari kullanımlara izin verilmez. Ayrıntılı bilgi için açık erişim politikasına bakınız. Hacettepe Üniversitesi İletişim Fakültesi tarafından yayınlanmıştır. 


\title{
AN EVALUATION ON UNDERGRADUATE NEW MEDIA EDUCATION AND EXPECTATIONS OF THE SECTOR IN TURKEY
}

\begin{abstract}
This study aims to classify all the obligatory and elective courses in the curricula of undergraduate new media departments in Turkey and quantitatively examine the general trends in higher education. In the field of digital/new media, which is regarded as a part of creative industries, classified advertisements in the sector have also been examined in order to present how much these tendencies in higher education overlap with the tendencies in the sector from a certain point of view. Within the scope of this study, classified advertisements were regarded as one of the indicators of sector expectations. Document analysis and content analysis methods were used together in the research. As a result of the research, it was found that certain higher education institutions, which claim to raise individuals to be employed in the field of digital media, would be useful to consider the expectations of the sector when carrying out curriculum development studies. It is also believed that in addition to this quantitative study which claims to be a beginning, it is necessary to conduct qualitative research using different methods such as in-depth interviews with all stakeholders to provide a more detailed analysis of general trends in higher education and sector in the future.
\end{abstract}

\section{Key Terms}

new media education, higher education, curriculum, creative industries, digital media.

\section{Giriş}

Tüm dünyada yaratıcı endüstrilerin bir kolu olarak kabul edilen sayısal/dijital/yeni medya $^{1}$ alanında, Türkiye'de yükseköğretim düzeyinde verilen eğitimi niceliksel olarak incelemeyi hedefleyen bu çalışmada, öncelikle yeni medya kavramına değinilmiş ve dünyadaki yeni medya eğitimine dair genel bir tablo sunulmuştur. Ardından yaratıcı endüstriler kavramı açıklanmış ve yaratıcı endüstriler ile eğitimi ilişkilendirerek inceleyen bilimsel çalışmalardan örnekler verilmiştir. Niceliksel bir analiz yapma hedefinde olan bu çalışmada, doküman inceleme ve içerik analizi yöntemleri birlikte

\footnotetext{
1 İngilizce "digital media" ifadesindeki "digit" sayı anlamına gelir. Bu nedenle öz Türkçe sayısal medya olarak tercüme edilmiştir. Ancak üniversitelerdeki bölümler "yeni medya" olarak açılmıştır ve sektördeki iş ilanlarında ise "dijital medya" olarak kullanıldığı görülmektedir. Bu gerekçelerle, bu çalışmada kimi zaman "yeni medya" kimi zaman da "dijital medya" ifadesi tercih edilmiştir.
} 
kullanılarak bir araştırma tasarlanmıştır. Buna göre, araştırma örneklemine dahil edilen belirli üniversitelerin lisans düzeyindeki yeni medya bölümlerinin müfredatları medyanın farklı alanlarına göre sınıflandırılarak analiz edilmiştir. Böylelikle Türkiye' deki yükseköğretimde yeni medya alanındaki genel eğilimlerin niceliksel olarak ortaya konması hedeflenmiştir. Ardından yaratıcı işgücü arayışında olan şirketlerin yeni medya ve benzeri alanlardan mezun olan bireylerde aradıkları nitelikleri sıraladıkları, sektör beklentilerinin göstergelerinden biri olarak kabul edilen iş ilanları incelenmiştir. Buna göre, iş ilanları üzerinden sektör beklentileri ile eğitimdeki genel eğilimlerin nicel analizi birlikte değerlendirilmiş ve yaratıcı işgücü yetiştirme iddiasında olan üniversitelerin sektörün beklentilerini dikkate alan müfredat çalışması yapmasının faydalı olacağı bulunmuştur.

$\mathrm{Bu}$ çalışma, nitel bazı sonuçlara ulaşma iddiasında değildir. $\mathrm{Bu}$ nedenle, üniversitelerdeki müfredatların mezunlarına iddia edilen bilgi ve becerileri kazandırıp kazandırmadığı tartışması nitel bir tartışma olduğu için ve de tüm paydaşlarla derinlemesine görüşmeler yapılarak belirlenebileceği için bu çalışmada kapsam dışı bırakılmıştır. Benzer şekilde, sektörün beklentileri ve de ihtiyaçları için sadece iş ilanları üzerinden bazı genel sonuçlara ulaşılamayacağından, sektörün ihtiyaçlarının belirlenmesinde sektör temsilcileri ile derinlemesine görüşmeler yapılarak nitel ihtiyaç analizi yapılmasının yararlı olacağı düşünülmektedir. Buna göre bu çalışmanın yanıt aradığı araştırma sorusu ve varsayımları şunlardır:

- Yaratıcı endüstrilerin bir kolu olarak kabul edilen dijital/yeni medya alanında, yükseköğretimdeki eğilimlerle sektörün beklentilerinin göstergelerinden biri olarak kabul edilen iş ilanlarındaki eğilimler ne kadar örtüşmektedir?

- Yükseköğretimdeki yeni medya eğitiminde yapılan müfredat analizinde üniversitelerin dersler açısından asgari düzeyde ortaklaştığı varsayılmaktadır.

- Dijital medya alanındaki iş ilanlarında aranan bilgi ve beceriler konusunda şirketlerin asgari düzeyde ortaklaştığı varsayılmaktadır.

- Üniversitelerdeki ve sektör beklentilerindeki eğilimlerin belirli bir düzeyde örtüştüğü varsayılmaktadır.

\section{Yeni medya eğitimi}

Dünyada iletişim/gazetecilik eğitimi ilk olarak ABD'de Missouri Üniversitesi'nde kurulan gazetecilik okulu ile başlamıştır. Türkiye' de yükseköğretimde medya alanındaki eğitimin başlangıcı ise 1950'li yıllardır. Tokgöz'e (2003) göre, 1950'de İstanbul 
Üniversitesi, İktisat Fakültesi Gazetecilik Enstitüsü “gazetecilik eğitimi”ne, 1965'te ise Ankara Üniversitesi Siyasal Bilgiler Fakültesi Basın Yayın Yüksek Okulu "iletişim eğitimi"ne başlar. 1970'lere gelindiğinde beş üniversitede iletişim eğitimi verilmekteyken, 1990'lardan sonra pek çok devlet ve vakıf üniversitesinde medya alanında eğitim verilmeye başlanmıştır (Tokgöz, 2003). Günümüzde hem devlet hem de vakıf üniversitelerinde iletişim fakültelerinin yanı sıra, güzel sanatlar fakültesi, iktisadi, idari ve sosyal bilimler fakültesi ve uygulamalı bilimler yüksekokulu bünyelerinde medya ile ilgili alanlarda eğitim verildiği görülmektedir.

Gazetecilik, Radyo, Televizyon ve Sinema, Halkla İlişkiler ve Tanıtım, Reklamcılık, Görsel İletişim Tasarımı gibi medyanın temel alanlarındaki iletişim eğitimine ek olarak ilk defa 2009 yılında İstanbul'da kurulmuş bir vakıf üniversitesi olan Kadir Has Üniversitesi, İletişim Fakültesi bünyesinde Yeni Medya eğitimine başlamıştır. YÖK'ün 2018 yılı Tercih Atlasında Türkiye Cumhuriyeti sınırları içerisinde yer alan ve adında Yeni Medya/Dijital Medya geçen toplam 20 lisans programında eğitim verildiği tespit edilmiştir. Ayrıca devlet ve vakıf olmak üzere toplam yedi üniversitede de yeni medya alanıla ilgili yüksek lisans programları vardır.

Son 10 yıl içerisinde Türkiye' de birçok devlet ve vakıf üniversitesinde açılan yeni medya bölümlerindeki eğitimi değerlendirmeden önce, yeni medya kavramı etrafındaki farklı yaklaşımlara ve kavramsal tartışmalara kısaca değinmek gerekir. The Language of New Media (Yeni Medyanın Dili) kitabında Lev Manovich (2002) yeni medyayı, medya ve bilgi teknolojileri arasındaki yakınsama sonucunda medyanın sayısallaşması olarak değerlendirirken, Convergence Culture (Yakınsama Kültürü) adlı kitabında Henry Jenkins (2006), medyanın gazete, radyo, televizyon gibi geleneksel platformlardan internet ve mobil gibi yeni platformlara geçişi olarak yorumlar. Buna göre, yeni medya; bilgi teknolojileri, telekomünikasyon ve medya sektörlerinin yakınsaması sonucu ortaya çıkmıştır. Dijital medya, yakınsak medya, elektronik medya veya sayısal medya olarak da anılmasına rağmen akademik yazında yaygın olarak yeni medya kavramı tercih edilmektedir. Yeni medya tanımlarında sıklıkla kullanılan kavramlardan bazıları "yakınsama, sanal gerçeklik, etkileşimsellik, küreselleşme, bilgi ekonomisi, ağlar, siber mekân, kolektif zekâ, mahremiyet, gözetim" (Flew, 2014), hipermetinsellik, çoklu ortam (multimedya) biçimselliği, kullanıcı türevli içerik üretimidir. Van Dijk'a göre ise, "yeni medya, geleneksel medyadan (gazete, radyo, televizyon, sinema) farklı olarak, dijital kodlama sistemine temellenen, iletişim sürecinin aktörleri arasında eş anlı ve çok yoğun kapasitede, yüksek hızda karşılıklı ve çok katmanlı etkileşimin gerçekleştiği multimedya biçimselliğine sahip iletişim araçlarıdır (aktaran Binark, 2007, s.5). 
Yeni medya ve eğitim ilişkisini inceleyen akademik çalışmalar genellikle yeni teknolojik araçlarla birlikte eğitimin dönüşmesi gerektiğine odaklanmakta ve dijitalleşen eğitimde yeni medyanın araç olarak katkısını incelemektedir. Yine çokça incelenen alanlardan biri de yetişkinlerde ve çocuklarda dijital medya okuryazarlığı eğitiminin niteliğidir. Ayrıca yeni medyanın çalışma alanlarından biri olan sosyal medya platformlarının gazetecilik, halkla ilişkiler, reklamcılık, tasarım gibi medya eğitiminin farklı alanlarında kullanımı üzerine yapılan birçok akademik çalışma da mevcuttur. Yukarıdakilere ek olarak, bazı uluslararası konferanslarda, (Deng, Ma ve Fong, 2018; Dutton ve Loader, 2002) medya ve eğitimle ilişkili bazı akademik dergilerde, tüm bir sayının (Buckingham, 2007) yeni medyanın uzaktan eğitim için kullanımı, mobil araçların, dijital oyunların, sosyal medyanın eğitimdeki önemi gibi konuların tartışıldığı gözlemlenmektedir. Benzer şekilde, dijital medya programlarının (software) ve internetin eğitimde kullanılmasının katılıma medya kültürünün gelişmesine olumlu katkısının internetteki metinler üzerinden incelendiği (Peppler, vd., 2007) çalışmalar ve yeni medya sanatı eğitimini ele alan bazı çalışmalar da mevcuttur (Sweeny, 2015).

Bunların yanı sıra, farklı coğrafyalarda dijital medya eğitiminin nasıl olması gerektiğini tartışan bazı araştırmalar da mevcuttur. Örneğin Rusya'daki medya eğitimini inceleyen Federov (2014), medya eğitimcileri ile yaptığı görüşmeler sonucunda, finansal zorluklar ve medya eğitimcilerinin kuram ve yöntem konusundaki bilgi eksiklikleri gibi nedenlerle bazı sorunlar yaşadığını bulgulamıştır. Bir başka örnekte Park ve Biddix (2008), Kore' deki dijital medya eğitimini inceler. Yazarlara göre, dijital medya eğitiminin güçlendirmek ve korumak gibi iki önemli öğesi vardır. Koreli gençlerin dijital medyadan en iyi şekilde nasıl yararlanabileceklerine, yani kendilerini geliştirebileceklerine ve de zararlı yönlerinden nasıl korunabileceklerine odaklanıldığını belirtir. Özellikle genç işsizliğindeki artış nedeniyle Kore hükümetinin bilgisayar programları (software) eğitimine olanak sağladığını, bunun yanında basın kurumlarının ve de Kültür ve Turizm Bakanlığının da dijital medya eğitimine destek olduğunu, ancak hükümetin uluslararası kuruluşlarla iş birliği yaparak daha genel bir dijital medya eğitimi planlaması yapmasının faydalı olacağını belirtir.

Yukarıdaki araştırmaların yanı sıra, yeni medya eğitimi ve sektör arasındaki ilişkiyi inceleyen az sayıda çalışma da mevcuttur. Örneğin, Fleischmann ve Daniel (2010), otantik gerçek-yaşam senaryolarını temel alan projeler ve bu projelere sektörden profesyonellerin geribildirimde bulunduğu dijital medya tasarımı eğitiminin, sınıf ortamında endüstrinin kopyasını üretmek ve böylelikle öğrencilerin profesyonel yaşama geçişlerini kolaylaştırmak anlamında faydalı olacağını ortaya koyar. Yazarlar, 
Avusturalya' daki araştırmalarında bu yöntem ile eğitim alan öğrencilerin daha karmaşık projeleri tamamlayabildiğini ve disiplinlerarası takımlarla çalışmanın öğrenmeyi zenginleştirdiğini bulmuşlardır. Benzer şekilde Avusturalya'daki bir başka araştırma, dijital medya profesyonellerinin öğrenme stratejilerinden yükseköğretimin neler kazanabileceğini tartışır (Bridgstock, 2016). Avusturalya'da çevrimiçi yayıncılık, oyun, uygulama, bilgisayar programı geliştiriciliği gibi mesleklerde çalışan profesyonellerle yapılan görüşmeler sonucunda, yükseköğretimdeki pedagojik yaklaşımların dijital çağda profesyonel yeterlilikleri geliştirmek konusunda pek de yardımcı olmadığı ortaya konmuştur. Bu nedenle, söz konusu profesyonellerin kuram ve uygulamayı birleştiren, kendi kendine ve toplulukla birlikte (sosyal) uygulayarak gayri-resmi (informal) öğrenme gibi öğrenme stratejilerinin 21. yüzyıl eğitimi için model alınabileceğini ileri sürülür.

Yurt dışındaki çalışmalarla benzer şekilde, Türkiye'de yeni medya üzerine yapılan akademik çalışmalarda da yeni medya eğitiminin nasıl olması gerektiği, yeni medya müfredatı ya da yükseköğretim politikası geliştirme üzerine çok fazla odaklanılmadığı gözlemlenmiştir. Yükseköğretim Kurulu (YÖK) ulusal tez merkezinde (tez.yok.gov.tr) "iletişim eğitimi" anahtar kelimeleri ile yapılan taramada yükseköğretimdeki iletişim eğitimini inceleyen üç tez (Aslan, 2017; Can, 2017; Yengin, 2017) olduğu ve "medya eğitimi" anahtar kelimeleri ile yapılan taramada, genellikle medya okuryazarlığ 1 eğitimine odaklanıldığı (Seylan, 2008; Koç, 2016; İnan, 2010; Dumlu, 2018; Kutlu, 2018; Ekşioğulları, 2018; Yıldız, 2011; Bakan, 2010; Aslan, 2009) gözlemlenmiştir. "Yeni medya eğitimi" anahtar kelimeleri ile yapılan taramada ise hiçbir sonuç elde edilememiştir. Sonuç olarak, ulusal tez merkezindeki verilere göre, yükseköğretimdeki iletişim eğitimi konusunda az sayıda çalışma vardır ve yeni medya eğitimi ise bugüne kadar hiçbir tezde anahtar kelime olarak kullanılmamıştır.

Bunlara ek olarak, ulusal boyutta oldukça yüksek katılımcıya sahip olan Alternatif Bilişim Derneği tarafından 2013'ten bu yana her iki yılda bir düzenlenen Yeni Medya Çalışmaları Ulusal Kongresi'nin (yenimedya.org.tr) ilk üçünde, yükseköğretimde yeni medya eğitimi konusunun hiçbir bildiride incelenmediği de tespit edilmiştir.

Benzer şekilde, Dergipark platformunda "yeni medya" anahtar kelimelerini kullanan yaklaşık 200 çalışmadan sadece bir tanesinin yeni medya eğitimini incelediği bulunmuştur. Söz konusu çalışmada Akdağ ve Akgül (2017), biri devlet sekizi vakıf olmak üzere toplam dokuz Yeni Medya lisans bölümünün müfredatlarını yönetim bilimleri, iletişim bilimleri, toplum bilimleri, sanat-tasarım ve bilişim olmak üzere beş kategoride niceliksel olarak incelemiş, sonuçta incelenen üniversitelerin müfredatlarında 
büyük farklılıklar olduğunu ve yeni medya eğitiminde özgün bir yazının oluşmadığını ileri sürmüşlerdir.

Bunlara göre, 2009'dan bu yana Türkiye'deki birçok devlet ve vakıf üniversitesinde lisans ve yüksek lisans düzeyinde eğitim verilen yeni medya eğitiminin, müfredat ve eğitim politikası geliştirme, sektörle ilişkilendirilme anlamında alan yazında pek fazla incelenmediği görülmektedir. Bu anlamda bu çalışma yükseköğretimdeki yeni medya eğitimini yaratıcı endüstriler bağlamında sektörel beklentilere göre nicel olarak analiz eden ilk çalışmadır.

\section{Yaratıcı endüstriler, temel kavramlar}

1990'lardan sonra Batılı ülkelerin akademik yazınında yaratıcı ve kültürel endüstriler kavramı kullanılmaya başlanmıştır. 1998'te Birleşik Krallık hükümeti Kültür, Medya ve Spor Departmanı'nın (DCMS) Birleşik Krallık'taki yaratıcı sektörleri (BOP Consulting, 2010) belirleyen çalışması ve 2015 yılında UNESCO'nun paydaşı olduğu ortak bir raporla (Cultural Times, 2015) birlikte bu alanın sınırları daha net çizilmiştir.

Birleşik Krallık'taki yaratıcı sektörler şunlardır (BOP Consulting, 2010): Reklamcllık; mimari, sanat ve antika pazarı; el sanatları, görsel sanatlar; tasarım, grafik ve moda tasarımı; film ve video, etkileşimli bilgisayar programları (interactive leisure software); müzik, performans sanatları; yayıncılık, bilgi-işlem, yazılım ve bilgisayar hizmetleri; televizyon ve radyo. Bunlara ek olarak İspanya ve Fransa'da, kütüphanecilik ile müze ve kültürel miras alanı da yaratıcı ve kültürel endüstriler arasında tanımlanmaktadır (BOP Consulting, 2010). Buna göre, çeşitli alanları barındırmasına rağmen yaratıcı endüstriler bazı özellikler açısından ortaklaşmaktadır. İşgücü ve fikri mülkiyet haklarına dayalı yaratıcı becerilerden ticari kazanç elde eden endüstrilerdir. Ayrıca yaratıcı endüstriler diğer endüstriyel sektörlerle birlikte işleyen daha geniş bir ekonomik yapı için yenilik kaynağıdır, yeni iş yaratma potansiyeline sahiptirler ve tüm bunlar yaratıcı ekonomileri oluşturur (BOP Consulting, 2010, s.12).

Cultural Times raporuna göre (2015), kültürel ve yaratıcı endüstriler; "temel amacı kültürel, sanatsal veya kültürel-miras bağlantılı öze sahip olan ürünlerin, hizmetlerin ve faaliyetlerin üretim veya yeniden üretim, promosyon, dağıtım veya ticarileşmesi faaliyetleri" olarak tanımlanmaktadır. Buna göre raporda küresel ölçekte beş bölgede 11 sektör belirlenmiştir (2015, s.11). Bu sektörler; reklamcllık (reklam ajansları), mimari (mimarlık şirketleri), kitaplar (bilimsel, teknik ve tıbbi kitaplar dahil basılı ve dijital kitap satışları), oyun (video oyunları yayıncıları, geliştiricileri ve perakende satış yapanlar, 
oyun ekipmanı satanlar), müzik (ses kayıt ve müzik yayın endüstrisi, canlı müzik), filmler (film prodüksiyon, post-prodüksiyon ve dağıtım), gazete ve dergiler (gazete ve dergi basım endüstrisi, haber ajansları), performans sanatları (performans sanat faaliyetleri; dans, tiyatro, canlı müzik, opera, bale, vb.), radyo (radyo yayını faaliyetleri), televizyon (televizyon programcılığı, kablo ve uydu yayıncılığı), görsel sanatlar (görsel sanat üretimi, müzeler, fotoğraf ve tasarım faaliyetleri).

Yaratıcı endüstrilerle ilgili bir başka rapor da, Birleşmiş Milletler Ticaret ve Kalkınma Konferansı raporudur (UNCTAD, 2010). Rapora göre; kültürel miras, performans sanatları, görsel sanatlar, işitsel-görsel ürünler (audiovisulas), yayıncılık ve basılı medyaya ek olarak yeni medya da yaratıcı endüstriler arasında ayrı bir başlık olarak incelenmiş ve yaratıcı endüstriler arasındaki en yeni grup olarak tanımlanmıştır. Rapora göre, yeni medyanın yaratıcı ekonomi içerisinde iki tamamlayıcı rolü vardır: "Yeni medya, çizgi filmler, bilgisayar programları gibi yaratıcı içeriklerin ve video oyunları gibi etkileşimli ürünlerin dijital biçimleri yoluyla ifade edilen başlı başına yaratıcı bir üründür." Ayrıca, "müzik, film, kitap ve haberler gibi diğer yaratıcı ürünlerin veya reklamcılık ve mimari hizmetler gibi yaratıcı hizmetlerin dağıtımı ve pazarlaması için bir araç olarak kullanılabilen bir bağlantısallıktır (connectivity)" (UNCTAD, 2010, s.158). Rapora göre yeni medya sektörü, çok oyunculu bilgisayar oyunları, videolar, çizgi filmler ve çokluortam içerikleri sayesinde iş birliğine açık (collaborative) yeni ortamlar olarak giderek gelişmektedir. Ek olarak, en büyük yeni medya ürünleri ihracatçısının ABD olduğu ve Avrupa'da ise Almanya, Hollanda, Avusturya ve Birleşik Krallık'ın öncü olduğu belirtilmektedir.

Yaratıcı endüstriler kavramını geliştiren gelişmiş ülkelerde konuyla ilgili akademik yazında ve çeşitli kuruluşların raporlarında kavramın eğitim ile olan ilişkisi de incelenmiştir. 2008-2010 yılları arasında Birleşik Krallık'ta gerçekleştirilen bir araştırmada (Ball vd., 2010, s.1) 2002, 2003 ve 2004 yıllarında sanat, el sanatları, tasarım ve medya alanlarından mezun olan 3500 kişinin kariyerleri incelenmiştir. Araştırmaya göre her beş kişiden dördü yaratıcı mesleklerde maaşlı çalışmaktadır, \%77'si yaptıkları işten memnundur. Mezunlar lisans derslerindeki eğitimin mesleklerindeki temel becerileri kazandırdığını, fakat IT ve müşteri ilişkileri konusunda beceri kazanamamış olduklarını ileri sürmüşlerdir. Katılımcıların \%72'si mezun olduktan sonra bazı beceriler için resmi olmayan (informal) eğitimler aldıklarını veya yükseköğretime devam ettiklerini de belirtmiştir. Ball vd.'ye (2010, s.11) göre, mezunlar, yaratıcı endüstriler ve yükseköğretim arasındaki ilişki arz-talep dengesi ile açıklanamayacak denli karmaşık bir olgudur. Akademik ortamdaki yaratıcı uygulamalar, kişisel ve profesyonel gelişime 
olanak sağlamaktadır ve mezunlar iş yaşamında da benzer bir model kurmaktadır. Yazarlara göre, müfredatlarda, iş birliği içerisinde öğrenmeye odaklanan yaratıc uygulamaları kapsayan yenilikler yapılmalıdır.

Bunun yanı sıra, Birleşik Krallık'taki Yaratıcı Medya Endüstrileri için Stratejik Beceri Değerlendirmesi başlıklı rapor (Creative Skillset, 2010) konuyla ilgili politika geliştirilmesine yarayacak bazı öneriler sunar. Bunlardan biri, mezunların işe alınması ve eğitilmesi için staj ve çıraklık eğitiminin uygulamaya konmasıdır. Özellikle film ve televizyon endüstrisi için çıraklık ve işte öğrenmenin (on-the-job training) faydalı olacağı belirtilir.

Benzer şekilde, Cultural Work and Higher Education başlıklı kitaplarında Ashton ve Noonan, kültürel ve yaratıcı endüstrilerin büyümesinde ve başarı kazanmasında yükseköğretimin çok önemli bir rol oynadığını ancak sürecin bazı zorlukları içerdiğini belirtir (2013, s. 255-259). Kitaba katkıda bulunan diğer yazarlar, yaratıcı disiplinlerdeki müfredatların, teori ve pratik arasındaki sınırı ortadan kaldırdığını ve akademik-mesleki (vocational) ayrımının silikleştiğini belirtirler. Ayrıca, öğrencilerin sektördeki farklı iş modellerinin, eşitsizliklerin vb. farkına varmalarını sağlayacak eleştirel bakışı kazanmalarının önemli olduğunu vurgularlar. Yazarlar, konunun öğrenciler, eğitimciler ve yaratıcı endüstrilerde çalışan uygulayıcılarla birlikte çok boyutlu olarak değerlendirilmesi gerektiğini ileri sürerler.

Yurt dışı yazına benzer şekilde, Türkiye'de de yaratıcı endüstrilerle ilgili yayınlanan raporlar mevcuttur. Örneğin, İstanbul Bilgi Üniversitesi, Kültür Politikaları ve Yönetimi Araştırma Merkezi tarafından gerçekleştirilen İstanbul Yaratıcı Ekonomi Çalışmaları Atölyesi'nde Türkiye'nin yaratıcı endüstrileri müzik, film, yayın ve halkla ilişkiler ve reklamcılık alanlarından değerlendirilmiştir. Atölyenin final raporu, (YEKON, 2014) Türkiye' deki en büyük eksikliğin yaratıcı endüstri merkezleri olduğunu belirtir ve bunun için fiziki merkezlerin yanında sanal portallar da açılması gerektiğini, yaratıcı sektörlerin finansal destek ihtiyacının karşılanması için özel fonların oluşturulması gerektiğini ve yaratıcı mesleklerle ilgili farkındalık yaratılmasına yönelik kampanyalar yapılması gerektiğini savunur.

Ancak yaratıcı endüstrilerle ilgili olarak Türkiye' deki yazına bakıldığında, yaratıcı endüstrilerin eğitimle ilişkisini ele alan az sayıda çalışma olduğu gözlemlenmiştir. YÖK Ulusal Tez merkezinde "yaratıcı endüstri" anahtar kelimeleri ile bir tarama yapıldığında 2009-2018 yılları arasında tez başlığında bu kavramı kullanan 12 tez olduğu tespit edilmiştir (tez.yok.gov.tr). Bu tezlerin büyük kısmının işletme, şehircilik ve bölge planlama ve endüstriyel tasarım gibi bölümlerdeki programlarda yapılmış olan tezler 
olduğu görülmektedir. İletişim bilimleri alanındaki bir tez (Şimşek, 2018) televizyon filmi senaryoları üzerine, bir diğeri (Aslan, 2018) de Latin Amerika pazarındaki Türk dizileri üzerinedir. Buna göre iletişim bilimleri alanında yaratıcı endüstriler konusunun yeni yeni incelenmeye başladığ görülmektedir. Buna ek olarak, incelenen tezlerden sadece bir tanesinin yaratıcı endüstriler ve eğitim arasındaki ilişkiyi incelediği tespit edilmiştir. İstanbul Teknik Üniversitesi, Fen Bilimleri Enstitüsü, Şehir ve Bölge Planlama Ana Bilim Dalı, Bölge Planlama Bilim Dalı yüksek lisans programında Büşra Güven tarafından 2017'de üretilen "Yaratıcı Endüstrilerde Eğitim ve İşgücü İlişkisi: İstanbul Çalışması" başlıklı tez, "yaratıcı işgücü eğitim ilişkisi, üniversiteler, endüstri beklentileri ve işbirlikleri çerçevesinde ortaya koymayı hedefler... Araştırmada seçilen endüstrilerde belirlenen üniversiteler ve meslek kuruluşları ile literatür araştırmalarına paralel derinlemesine mülakatlar yapılmıştı²"' (Güven, 2017).

Benzer şekilde, yaratıcı endüstriler ve eğitim konusunu inceleyen, az sayıda tez harici akademik çalışma olduğu da tespit edilmiştir. Bunlardan biri, yukarıdaki bahsi geçen tezin yazarı ve danışmanı tarafından kaleme alınan İstanbul'daki yaratıcı işgücünün eğitimi konusundadır (Kerimoğlu ve Güven-Güney, 2018). Çalışmada reklamcılık, mimarlık, endüstriyel tasarım ve grafik tasarım bölümlerindeki öğretim elemanları ve meslek kuruluşları ile derinlemesine mülakatlar yapılmıştır. Araştırmanın bulgularına göre, eğitim kurumları endüstri ile daha fazla iş birliği yapılmasını, meslek kuruluşları ise gelenekselin ötesinde öğrencilerin daha serbest bırakıldığı, "öğrencilerin esnek ve çeşitlendirilmiş projelere yönelik çalıştırılması" ve eğitim ile endüstrinin iş birliği içerisinde olması gerektiğini ileri sürmüşlerdir. Yazarlar, endüstrinin ihtiyaçları ile mevcut eğitim sistemi arasında boşluk olduğu ve her iki taraf arasında bağ kurulması gerektiği sonucuna ulaşırlar.

Konuyla ilgili bir başka çalışmada Türkiye'deki yaratıcı endüstrileri inceleyen Demir (2014, s.103) yaratıcı endüstrilerin yükseköğretimi yapısal olarak dönüştürme potansiyeli olan politikalara etki edebileceğini ve öğrencilerin yükseköğretimden beklentilerini de değiştirebileceğini ileri sürer. Yükseköğretimin piyasanın ihtiyaçlarına göre şekillendirilmesinin ise tehlikeli sonuçları olabileceğini ama konunun mutlaka ayrıntılı olarak akademi tarafından tartışılması gerektiğini savunur. Türkiye'de yaratıcı emek konulu bir başka çalışmasında Demir (2018), Türkiye'deki preker çalışma koşullarını sektörden katılımcılarla yaptı̆̆ı anket çalışması sonuçlarından yola çıkarak

2 Söz konusu teze 03.02.2020 tarihine kadar erişim kısıtı olduğu için daha detaylı bir inceleme yapılamamıştır. 
değerlendirmiştir. Demir (2018), Türkiye'de 392 katılımcı ile yürüttüğü araştırmasında, Beşeri Bilimler ve Sanat eğitimi alan yaratıcı çalışanların yükseköğretimlerinin iş yaşamına katkısını olumlu olarak değerlendirdiklerini tespit eder. Öneriler başlı̆̆ altında "katılımcıların yarıdan fazlası (\%56) resmi eğitimin güncel teknolojik ve toplumsal değişimi tam olarak karşılayamadığı ve/veya öğrencileri sektör dinamiklerine yeterince hazırlamadığı yönünde fikir" bildirirler ve katılımcıların tamamına yakını eğitimin geliştirilmesi için öneriler sunmuştur. Öneriler arasında "sektörle ilişkilerin ve uygulama sürelerinin arttırılması" öne çıkar (Demir, 2018, s.184). Ayrıca "öğrenciye sunulan katılım ve karar verme firsatlarının arttırılması" da yine önerilen konular arasındadır. Katılımcılar "öğretim üyelerinin sektörü yeterince tanımadığını" da ifade etmiştir. Akademik eğitimin önemini kabul etmekle beraber kuramın pratikle bağını kurmak için akademisyenlerin daha aktif rol alması talep edilir" (s.185). Demir'e (2018, s.185-186) göre yükseköğretimde "öğrencinin tercih ve ihtiyaçlarını öne çıkaran ve uygulama yoluyla öğrenilen kuramsal bilgilerin denenmesine imkân sağlayan daha açık bir öğrenme biçimi" küresel değişimle uyumludur. Doğal öğrenme konusunu da inceleyen Demir (2018, s.186-187) katılımcıların, yaratıcı eylemin yapıldığı yerde en iyi öğrenmenin gerçekleşeceğini belirttiğini ve ikinci olarak yükseköğretimi işaret ettiklerini de ileri sürer. Deneyimli bir danısman eşliğinde öğrenmenin ise önemli olduğu vurgulanır. Becerilerin de incelendiği çalışmada, "yeni özgün ve uygulanabilir fikirler" üretmek en önemli beceri olarak ortaya çıarken, "değişken ortamlar ve farklı paydaşlardan kaynaklanan etkileşimleri yönetmekle" ilişkili becerilerin de önemli olduğu bulgulanmıştır (s.187). Demir'e (2018, s.190) göre yaratıcı sektörlerde çalışanlar "daha yakın ve anlayışlı bir yükseköğretim hayal etmektedir", çalışma genel olarak daha iyi yaratıcı endüstri profesyoneli yetiştirmeye dikkat çekmektedir.

Sonuç olarak, yurt içinde ve yurt dışında yaratıcı endüstriler ve yükseköğretim arasındaki ilişkiyi inceleyen çalışmaların, bazı açılardan ortaklaşan bulgulara ulaştığı ve benzer öneriler sunduğu görülmektedir. Çalışmalara göre, katılımcılar yükseköğretimdeki eğitimden büyük oranda memnun olsalar da sektör ve eğitim arasında daha sıkı bir bağ olması gerektiği, uygulayarak ve işte öğrenme gibi yöntemlerin daha etkili olabileceği ve eğitimcilerin yeni teknolojik olanaklar ve sektör hakkında daha bilgili olmasının faydalı olacağını ileri sürmüşlerdir. 


\section{Araştırma}

Yaratıcı endüstriler ve eğitim arasındaki ilişkiyi inceleyen yazına katkıda bulunmak amacıyla, bu çalışmada, yükseköğretim müfredatlarındaki eğilimlerle sektör beklentilerinin bir göstergesi olarak kabul edilen iş ilanlarındaki eğilimlerin ne kadar örtüştüğü konusu, doküman inceleme ve içerik analizi yöntemleri kullanılarak değerlendirilmiştir. Bu çalışmada yeni medyadaki bu farklı yaklaşımların ve kavramların yükseköğretimdeki derslere yansıyıp yansımadığı da değerlendirilecektir.

Bu amaçla, öncelikle araştırma örneklemine dahil edilen yeni medya lisans bölüm müfredatlarındaki dersler, belirli ölçütlere göre sınıflandırılmıştır. Ardından yeni medya/dijital medya çalışanlarında aranan özellikler, çevrimiçi iş arama platformu üzerinde yayınlanan iş ilanları üzerinden değerlendirilmiştir. Bulgular yükseköğretim ve sektör beklentilerdeki genel eğilimlere göre yorumlanmıştır.

Araştırma evreni olarak, YÖK'ün 2018 yılı Tercih Atlasında (yokatlas.yok.gov.tr) Türkiye Cumhuriyeti sınırları içerisinde lisans eğitimi veren, adında Yeni Medya geçen üniversiteler ve bölümler alınmıştır. Tercih atlasında yer alan Kuzey Kıbrıs Türk Cumhuriyeti'ndeki üniversiteler, araştırmaya dahil edilmemiştir. Buna göre, adında Yeni Medya/Dijital Medya geçen bölümler: Biri devlet, yedi tanesi vakıf olmak üzere toplam sekiz üniversitede 10 adet "Yeni Medya" Bölümü (iki üniversitede hem Türkçe hem de İngilizce bölümler vardır), beş vakıf üniversitesinde "Yeni Medya ve İletişim", üç vakıf üniversitesinde "Yeni Medya ve Gazetecilik", bir vakıf üniversitesinde "Sinema ve Dijital Medya" ve bir devlet üniversitesinde "Yeni Medya ve İletişim Tasarımı"4 olmak üzere bu alanda toplam 20 lisans programında eğitim verildiği tespit edilmiştir. Bunlara ek olarak İstanbul'daki üç vakıf üniversitesinde "Dijital Oyun Tasarımı" bölümü vardır. Ayrıca devlet ve vakıf olmak üzere toplam yedi üniversitede de yeni medya alanıla ilgili yüksek lisans programı vardır. Söz konusu üniversiteler, fakülteler ve bölümler aşağıdaki tabloda sunulmuştur.

\footnotetext{
3 Yaşar Üniversitesi'ndeki bölüm, YÖK 2018 Tercih Atlasında Yeni Medya ve Gazetecilik olarak yayınlanmış, ancak üniversitenin kendi web sayfasında Yeni Medya ve İletişim olarak yayınlanmıştır. Bölüm müfredatı incelendiğinde gazetecilik ağırlıklı bir eğitim verildiği görüldüğü için Tercih Atlasındaki isim temel alınmış ve bu üniversitedeki bölüm "Yeni Medya ve Gazetecilik" kategorisi altında değerlendirilmiştir.

4 Ondokuz Mayıs Üniversitesi İletişim Fakültesi'nde "İletişim Tasarımı" adıyla 2012'de kurulan bölümün adı 2015 yılında Yeni Medya ve İletişim Tasarımı olarak değiştirilmiştir.
} 


\begin{tabular}{|c|c|c|}
\hline Üniversite & Fakülte & Bölüm \\
\hline Bahçeşehir Üniversitesi & İletişim & Yeni Medya (İng) \\
\hline Beykent Üniversitesi & İletişim & Yeni Medya (İng ve Tr) \\
\hline İstanbul Gelişim Üniversitesi & $\begin{array}{l}\text { İktisadi, İdari ve Sosyal } \\
\text { Bilimler }\end{array}$ & Yeni Medya (Tr) \\
\hline İstanbul Okan Üniversitesi & Uygulamalı Bilimler & Yeni Medya (Tr) \\
\hline Kadir Has Üniversitesi & İletişim & Yeni Medya (İng) \\
\hline Nişantaşı Üniversitesi (Tr) & $\begin{array}{l}\text { İktisadi, İdari ve Sosyal } \\
\text { Bilimler }\end{array}$ & Yeni Medya (Tr) \\
\hline Nişantaşı Üniversitesi (En) & $\begin{array}{l}\text { İktisadi, İdari ve Sosyal } \\
\text { Bilimler }\end{array}$ & Yeni Medya (İng) \\
\hline Uşak Üniversitesi (Devlet) & İletişim & Yeni Medya (Tr) \\
\hline İstinye Üniversitesi & $\begin{array}{l}\text { İktisadi, İdari ve Sosyal } \\
\text { Bilimler }\end{array}$ & Yeni Medya (İng) \\
\hline İstanbul Arel Üniversitesi & İletişim & Yeni Medya ve İletişim (Tr) \\
\hline İstanbul Aydın Üniversitesi & İletişim & Yeni Medya ve İletişim (Tr) \\
\hline İstanbul Kültür Üniversitesi & Sanat ve Tasarım & Yeni Medya ve İletişim (Tr) \\
\hline $\begin{array}{l}\text { İstanbul Medipol } \\
\text { Üniversitesi }\end{array}$ & İletişim & Yeni Medya ve İletişim (Tr) \\
\hline İstanbul Şehir Üniversitesi & İletişim & Yeni Medya ve İletişim (İng) \\
\hline $\begin{array}{l}\text { İstanbul Yeni Yüzyıl } \\
\text { Üniversitesi }\end{array}$ & İletişim & Yeni Medya ve Gazetecilik (Tr) \\
\hline Üsküdar Üniversitesi & İletişim & Yeni Medya ve Gazetecilik (Tr) \\
\hline Yaşar Üniversitesi & İletişim & $\begin{array}{l}\text { Yeni Medya ve Gazetecilik } \\
\text { (İng) }\end{array}$ \\
\hline İzmir Ekonomi Üniversitesi & İletişim & Sinema ve Dijital Medya (İng) \\
\hline Ondokuz Mayıs Üniversitesi & İletişim & $\begin{array}{l}\text { Yeni Medya ve İletişim } \\
\text { Tasarımı (Tr) }\end{array}$ \\
\hline Bahçeşehir Üniversitesi & İletişim & Dijital Oyun Tasarımı (İng) \\
\hline İstanbul Bilgi Üniversitesi & İletişim & Dijital Oyun Tasarımı (İng) \\
\hline Beykoz Üniversitesi & Sanat ve Tasarım & Dijital Oyun Tasarımı \\
\hline
\end{tabular}

Tablo 1: YÖK 2018 Tercih Atlasına göre, Türkiye Cumhuriyeti sınırları içerisinde eğitim vermekte olan Yeni Medya ve yeni medya ile ilgili bölüm, fakülte ve üniversite bilgileri.

Tercih atlasında yer almayan ancak üniversitelerin kendi web sitelerinde yayınlanan, henüz eğitim vermeye başlamamış olan bazı başka bölümler de vardır. Söz konusu üniversitelerin bu bölümlerinde, henüz eğitim verilmeye başlanmadığı ve web 
sayfalarında yayınlanmış bir müfredatları olmadığı için bu bölümler araştırmada kapsam dışı bırakılmıştır. Bahsi geçen üniversiteler ve bölümler şunlardır: Çanakkale Onsekiz Mart Üniversitesi, İletişim Fakültesi, Yeni Medya Bölümü; Pamukkale Üniversitesi, İletişim Fakültesi Yeni Medya Bölümü; Fenerbahçe Üniversitesi, İletişim Fakültesi, Yeni Medya Bölümü.

Lisans programlarına ek olarak, Türkiye Cumhuriyeti sınırları içerisindeki bazı devlet ve vakıf üniversitelerinde hali hazırda yeni medyayla ilişkili yüksek lisans programlarının da olduğu tespit edilmiştir. Bu üniversiteler ve programlar şöyledir: İstanbul Üniversitesi Yeni Medya ve İletişim Yönetimi Yüksek Lisans Programı; Gazi Üniversitesi Yeni Medya Yüksek Lisans Programı; Ege Üniversitesi Sosyal Medya ve Dijital İletişim Yüksek Lisans Programı; İstanbul Aydın Üniversitesi Yeni Medya Yüksek Lisans Programı; İstanbul Gelişim Üniversitesi Yeni Medya İletişim ve Habercilik Yüksek Lisans Programi; Kadir Has Üniversitesi Yeni Medya Yüksek Lisans Programı; Üsküdar Üniversitesi Yeni Medya ve Gazetecilik Yüksek Lisans Programı.

Araştırmanın örneklemi, Türkiye'deki tüm devlet ve vakıf üniversitelerinde lisans düzeyinde eğitim veren "Yeni Medya" ve "Yeni Medya ve İletişim" adıyla açlan bölümlerdir. "Yeni Medya ve Gazetecilik", “Dijital Medya ve Sinema”, "Yeni Medya ve İletişim Tasarımı”, “Dijital Oyun Tasarımı” gibi bölümlerin medyanın belirli bir alanına odaklandığı düşünüldüğünden araştırmaya dahil edilmemiştir. Yine tüm devlet ve vakıf üniversitelerindeki "Yeni Medya" adlı yüksek lisans programları da temel düzeyde eğitim verme hedefi olmadığı varsayıldığından araştırmada kapsam dışı bırakılmıştır.

Örnekleme göre sadece bir tane devlet üniversitesinde, Uşak Üniversitesi'nde Yeni Medya Bölümü'nde eğitim verildiği görülmektedir. Devlet üniversitelerinde Yeni Medya Bölümü kurulmamış olmasının nedenlerinden birinin, devlet üniversitelerindeki bürokratik yapının akademik kadro istihdamı, teknik olanaklar vb. nedeniyle yeni bölüm açmak konusunda vakıf üniversitelerine göre daha az esnek davranması olabilir. Örnekleme dahil edilen tüm vakıf üniversitelerinin İstanbul'da kurulan vakıf üniversiteleri olması da dikkat çekicidir. YEKON (2014) raporunda da belirtildiği gibi Türkiye'deki yaratıcı endüstrilerin büyük bölümü İstanbul'da konuşlanmaktadır. Bu bağlamda yaratıcı endüstrilerin bir kolu olarak, Yeni Medya Bölümlerinin İstanbul'daki vakıf üniversitelerinde açılmış olması kısmen anlamlıdır.

Örnekleme dahil edilen tüm bölümlerin en güncel ders programlarında yer alan tüm zorunlu ve seçmeli dersler incelenmesi sonucunda Tablo 2 ve Tablo 3'teki sınıflandırma yapılmıştır. Bölüm müfredatlarındaki Türkçe, İngilizce, Atatürk İlkeleri ve İnkılap Tarihi gibi YÖK zorunlu dersleri ile diğer yabancı dil dersleri tabloya dahil 
edilmemiştir. Bitirme tezleri, mezuniyet projeleri ve staj gibi uygulamalar, bölüm müfredatında zorunlu ders olarak yayınlandığı durumlarda bunlar, "yeni medyaya özgü dersler" başlı̆g 1 altında incelenmiş, zorunlu ders olarak belirtilmeyen müfredatlar için bunlar tabloya dahil edilmemiştir.

Kavramsal bölümde ifade edildiği gibi, Jenkins (2006) tarafından "medyanın gazete, radyo, televizyon gibi geleneksel platformlardan internet ve mobil gibi yeni platformlara geçişi" olarak yorumlanan yeni medyanın yükseköğretiminde, medyanın söz konusu platformlarını içinde barındıran bir eğitim sunması, doğal bir sonuç olarak ortaya çıkmaktadır. Buna göre örnekleme dahil edilen Yeni Medya müfredatlarındaki dersler için, bu platformlar dikkate alınarak bir sınıflandırma yapılmış ve ders kategorilerinin o üniversite için toplama göre hangi oranda olduğu yüzdelik olarak ifade edilmiştir. Tablo 2 ve Tablo 3'te yer alan kısaltmaların açılımları şöyledir: İB-İletişim bilimleriyle ilgili dersler; YM-Yeni medyaya özgü dersler; GZT-Gazetecilikle ilgili dersler; HIR-Halkla ilişkiler ve reklamcılıkla ilgili dersler; TAS-Tasarımla ilgili dersler; TV\&R-Televizyon ve radyo ile ilgili dersler; F\&V\&SIN-Fotoğraf, video ve sinema ile ilgili dersler; KÜLT-Kültürel çalışmalarla ile ilgili dersler. Son olarak bu alanların birinde yer almayan sosyal bilimler veya istatistik, girişimcilik gibi dersler de DİĞER kategorisi içerisinde sınıflandırılmıştır. İletişim bilimleriyle ilgili dersler kategorisinde, iletişime giriş, medya tarihi, iletişim kuramları, medya analizi, metin yazarlığı, iletişim hukuku, iletişim etiği, kültürlerarası iletişim, medya endüstrisi gibi dersler değerlendirilmiştir. Yeni medyaya özgü dersler kategorisine dahil edilen derslerden bazıları ise şöyledir: Yeni medya giriş, yeni medya teknolojileri, yeni medya kuramları, yeni medya okuryazarlığı, yeni medya sosyolojisi, yeni medya çalışmaları, yeni medyada araştırma yöntemleri, yeni medya uygulamaları, yeni medya programcılığı, yeni medya ve etik, dijital içerik yönetimi, sosyal medya, dijital platformlar, dijital oyun, mobil iletişim teknolojileri, mezuniyet projeleri, bitirme tezleri, staj vb. incelenen müfredatlarda belirtilen kategorilerde, zorunlu ve seçmeli kaç ders olduğu Tablo 2 ve Tablo 3 'te sunulmuştur. Tablolarda da belirtildiği gibi, İstanbul Medipol Üniversitesi'nin web sayfasında sadece 6 dönemlik bir müfredat yayınlandığı için, değerlendirme buna göre yapılmıştır. Ayrıca yine tablolarda Beykent Üniversitesi'nde hem Türkçe hem de İngilizce programlar olmasına rağmen tek bir müfredat sunulduğu için tek bir başlık altında değerlendirilmiş, buna karşın Nişantaşı Üniversite'nde Türkçe ve İngilizce Yeni Medya bölümleri için birbirinden farklı dersler içeren bölümlere özel müfredatlar yayınlandığı için ayrı ayrı değerlendirilmiştir. 


\begin{tabular}{|c|c|c|c|c|c|c|c|c|c|c|c|}
\hline \multirow[t]{2}{*}{ ÜNIVERSITE ADI } & \multirow[t]{2}{*}{ BÖLÜM } & \multicolumn{10}{|c|}{ ZORUNLU DERSLERIN SAYISI VE (YAKLAȘIK) YÜZDELIK ORANLARI } \\
\hline & & İB & YM & GZT & HIR & TAS & TV\&R & F\&V\&SIN & KÜLT & DİǦER & TOPLAM \\
\hline BAHÇEȘEHİR ÜNİ. & Yeni Medya (İng) & $6 / \% 25$ & $5 / \% 21$ & $6 / \% 25$ & & & & $1 / \% 4$ & $2 / \% 8$ & $4 / \% 17$ & 24 \\
\hline BEYKENT ÜNİ. & Yeni Medya (İng ve Tr) & $3 / \% 7$ & $12 / \% 29$ & $1 / \% 2$ & $5 / \% 12$ & $4 / \% 10$ & & $1 / \% 2$ & $2 / \% 5$ & $14 / \% 33$ & 42 \\
\hline İSTANBUL AREL ÜNİ. & Yeni Medya ve İletişim (Tr) & $12 / \% 35$ & $4 / \% 12$ & $2 / \% 6$ & $1 / \% 3$ & $2 / \% 6$ & $1 / \% 3$ & $3 / \% 9$ & $3 / \% 9$ & $6 / \% 18$ & 34 \\
\hline İSTANBUL AYDIN ÜNİ. & Yeni Medya ve İletişim (Tr) & $7 / \% 21$ & $21 / \% 62$ & & $1 / \% 3$ & $1 / \% 3$ & & & $1 / \% 3$ & $3 / \% 9$ & 34 \\
\hline İSTANBUL GELIȘiM ÜNİ. & Yeni Medya (Tr) & $11 / \% 29$ & $6 / \% 16$ & $2 / \% 5$ & $3 / \% 8$ & $3 / \% 8$ & $1 / \% 3$ & & $1 / \% 3$ & $11 / \% 29$ & 38 \\
\hline İSTANBUL KÜLTÜR ÜNİ. & Yeni Medya ve İletișim (Tr) & $4 / \% 10$ & $21 / \% 51$ & $2 / \% 5$ & $3 / \% 7$ & $2 / \% 5$ & & $1 / \% 2$ & $1 / \% 2$ & $7 / \% 17$ & 41 \\
\hline İSTANBUL MEDIPOL ÜNII.* & Yeni Medya ve İletișim (Tr) & $5 / \% 24$ & $4 / \% 19$ & $2 / \% 10$ & $2 / \% 10$ & $4 / \% 19$ & & & & 4/\%19 & 21 \\
\hline İSTANBUL OKAN ÜNİ. & Yeni Medya (Tr) & $5 / \% 17$ & $10 / \% 34$ & $2 / \% 7$ & $4 / \% 14$ & $3 / \% 10$ & & & $1 / \% 3$ & $4 / \% 14$ & 29 \\
\hline İSTANBUL ŞEHİR ÜNİ. & Yeni Medya ve İletișim (İng) & $5 / \% 24$ & $8 / \% 38$ & & $2 / \% 10$ & & & & $1 / \% 5$ & $5 / \% 24$ & 21 \\
\hline İSTINYE ÜNİ. & Yeni Medya (İng) & $7 / \% 26$ & $9 / \% 33$ & $1 / \% 4$ & $2 / \% 7$ & $4 / \% 15$ & & $3 / \% 11$ & $1 / \% 4$ & & 27 \\
\hline KADIR HAS ÜNİ. & Yeni Medya (İng) & $8 / \% 38$ & $9 / \% 43$ & $1 / \% 5$ & & $1 / \% 5$ & & & & $2 / \% 10$ & 21 \\
\hline NIȘANTAȘI ÜNİ.(TR) & Yeni Medya (Tr) & $5 / \% 33$ & $5 / \% 33$ & $1 / \% 7$ & $1 / \% 7$ & $1 / \% 7$ & & $1 / \% 7$ & $1 / \% 7$ & & 15 \\
\hline NIȘANTAȘI ÜNİ.(EN) & Yeni Medya (İng) & $6 / \% 25$ & $2 / \% 8$ & $2 / \% 8$ & $3 / \% 13$ & $4 / \% 17$ & & $3 / \% 13$ & $1 / \% 4$ & $3 / \% 13$ & 24 \\
\hline UȘAK ÜNİ. (Devlet) & Yeni Medya (Tr) & $10 / \% 33$ & $8 / \% 27$ & $2 / \% 7$ & $2 / \% 7$ & $2 / \% 7$ & & $2 / \% 7$ & & $4 / \% 14$ & 30 \\
\hline
\end{tabular}

Tablo 2: Örnekleme dahil edilen üniversitelerdeki zorunlu derslerin yukarıda belirtilen kategorilere göre sayıs1.

Tablo 2'de görüldüğü gibi, Yeni Medya bölümlerinde zorunlu derslerin, gazetecilik alanında bir üniversite hariç, tüm üniversitelerde toplam derslere oranı \%10'dan çok değildir. Yapılan incelemede Bahçeşehir Üniversitesi'ndeki bölümün adı sadece Yeni Medya olarak geçmesine rağmen, müfredatının neredeyse Yeni Medya ve Gazetecilik bölümlerindeki kadar yoğun biçimde, gazetecilikle ilgili dersler barındırdığı tespit edilmiştir. Tabloda halkla ilişkiler, reklamcllık alanlarındaki derslerin toplam derslere oranının en fazla \%14 olduğu, tasarım alanında en fazla \%19 olduğu görülmektedir. Sadece iki üniversitede radyo ve televizyonla ilgili ders vardır, onların oranı ise \% 3 'tür. Benzer şekilde, fotoğraf, video ve sinema alanında bazı üniversitelerde hiç ders yoktur, olanlarda en yüksek oran \%13'tür. Kültür alanındaki derslerin toplama oranı en yüksek $\% 9^{\prime}$ dur. İletişim bilimleri ile ilgili derslerde ise oran genellikle \%20-30 civarındadır ve en yüksek oran \%38'dir. Buna göre, üniversitelerin bu alanda temel bir eğitim verme hedefinde oldukları ileri sürülebilir. Yeni medyaya özgü derslerde İstanbul Aydın (\%62) ve İstanbul Kültür (\%51) üniversitelerinde oran oldukça yükselmekte ama genel olarak \%20-30'lar civarında olduğu görülmektedir. Sonuç olarak, Yeni Medya bölümlerindeki zorunlu dersleri incelediğimizde, üniversitelerin genel olarak iletişim bilimleri ve yeni medyaya özgü dersler vermeyi tercih ettiği görülmektedir. 


\begin{tabular}{|c|c|c|c|c|c|c|c|c|c|c|c|}
\hline \multirow[t]{2}{*}{ ÜNIVERSITE ADI } & \multirow[t]{2}{*}{ BÖLÜM } & \multicolumn{10}{|c|}{ SEÇMELI DERSLERIN SAYISI VE (YAKLAȘIK) YÜZDELIK ORANLARI } \\
\hline & & İB & YM & GZT & HIR & TAS & TV\&R & F\&V\&SiN & KÜLT & DíĞER & TOPLAM \\
\hline BAHÇEŞEHIR ÜNII. & Yeni Medya (İng) & $4 / \% 16$ & $7 / \% 28$ & $10 / \% 40$ & & $2 / \% 8$ & $1 / \% 4$ & & $1 / \% 4$ & & 25 \\
\hline BEYKENT ÜNİ. & Yeni Medya (İng ve Tr) & \multicolumn{10}{|c|}{ Seçmeli ders listesine ulaş̣lamamıștır. } \\
\hline ISTANBUL AREL ÜNİ. & Yeni Medya ve Illetișim (Tr) & 9/\%19 & $3 / \% 6$ & $3 / \% 6$ & $6 / \% 13$ & $2 / \% 4$ & $1 / \% 2$ & $17 / \% 35$ & & $7 / \% 15$ & 48 \\
\hline İSTANBUL AYDIN ÜNİ. & Yeni Medya ve İletișim (Tr) & $3 / \% 10$ & $16 / \% 55$ & $2 / \% 7$ & $3 / \% 10$ & $5 / \% 17$ & & & & & 29 \\
\hline İSTANBUL GELIȘIMM ÜNİ. & Yeni Medya (Tr) & \multicolumn{10}{|c|}{ Seçmeli ders listesine ulaşıllamamıștır. } \\
\hline İSTANBUL KÜLTÜR ÜNİ. & Yeni Medya ve Illetișim (Tr) & $1 / \% 4$ & $10 / \% 38$ & $1 / \% 4$ & $3 / \% 12$ & $6 / \% 23$ & & $2 / \% 8$ & $1 / \% 4$ & $2 / \% 8$ & 26 \\
\hline İSTANBUL MEDIPOL ÜNI.** & Yeni Medya ve İletișim (Tr) & $7 / \% 19$ & $4 / \% 11$ & $1 / \% 3$ & $5 / \% 14$ & $8 / \% 22$ & $4 / \% 11$ & 6/\%17 & $1 / \% 3$ & & 36 \\
\hline İSTANBUL OKAN ÜNI. & Yeni Medya (Tr) & $1 / \% 4$ & $8 / \% 31$ & $1 / \% 4$ & $5 / \% 19$ & $1 / \% 4$ & $3 / \% 12$ & $4 / \% 15$ & $1 / \% 4$ & $2 / \% 8$ & 26 \\
\hline İSTANBUL ȘEHIR ÜNI. & Yeni Medya ve İletişim (İng) & $6 / \% 9$ & $5 / \% 7$ & $3 / \% 4$ & $17 / \% 25$ & $4 / \% 6$ & $8 / \% 12$ & $22 / \% 32$ & $4 / \% 6$ & & 69 \\
\hline İSTINYE ÜNI. & Yeni Medya (İng) & $3 / \% 14$ & & & $5 / \% 23$ & $1 / \% 5$ & $1 / \% 5$ & $10 / \% 45$ & & $2 / \% 9$ & 22 \\
\hline KADIR HAS ÜNİ. & Yeni Medya (İng) & & $8 / \% 47$ & $3 / \% 18$ & $1 / \% 6$ & $5 / \% 29$ & & & & & 17 \\
\hline NiȘANTAȘI ÜNII. (TR) & Yeni Medya (Tr) & $3 / \% 14$ & $5 / \% 23$ & & $5 / \% 23$ & $7 / \% 32$ & & $1 / \% 5$ & & $1 / \% 5$ & 22 \\
\hline NISȘANTAȘI ÜNİ. (EN) & Yeni Medya (İng) & $1 / \% 5$ & $6 / \% 30$ & $1 / \% 5$ & $5 / \% 25$ & & & & & $7 / \% 35$ & 20 \\
\hline UȘAK ÜNİ. (Devlet) & Yeni Medya (Tr) & $4 / \% 13$ & $8 / \% 25$ & $5 / \% 16$ & $1 / \% 3$ & $4 / \% 13$ & $2 / \% 6$ & $2 / \% 6$ & $1 / \% 3$ & $5 / \% 16$ & 32 \\
\hline
\end{tabular}

*Üniversitenin web sayfasında sadece 6 dönemlik müfredat yayımlanmıștır.

Tablo 3: Örnekleme dâhil edilen üniversitelerdeki seçmeli derslerin yukarıda belirtilen kategorilere göre sayıs1.

Örnekleme dahil edilen üniversitelerdeki seçmeli derslerin çeşitliliği incelendiğinde, bazı ders kategorilerinde zorunlu derslerdekine benzer oranlar olduğu görülmektedir, örneğin yeni medyaya özgü dersler, gazetecilikle, kültürle ilgili dersler gibi. Buna karşın, üniversitelerin bazı kategorilerdeki oranları farklılaştırdığı da görülmektedir. Zorunlu derslere kıyasla seçmeli derslerde iletişim bilimleri alanındaki derslerin oranı daha düşüktür. Halkla ilişkiler ve tasarım derslerinin oranının ise, zorunlu derslere göre kıyaslandığında, yükseldiği görülmektedir. Daha fazla üniversitede televizyon ve radyo ile ilgili seçmeli ders sunulmuştur ve yine fotoğraf, video ve sinema derslerinin oranlarında da artış vardır. Bazı üniversitelerde ise kültür ile ilgili seçmeli ders yoktur. Diğer kategorisindeki oranlarda da zorunlu derslere göre düşüş vardır. Bu tabloya göre, üniversitelerin yine zorunlu dersler kategorilerindeki derslerle aynı alanlarda seçmeli ders vermeyi tercih ettiği görülmektedir.

Sonuç olarak örnekleme dahil edilen üniversitelerde yukarıda bahsi geçen medyanın farklı alanlarını kapsayan çeşitlikte ders verdikleri, bu çeşitliliğin zorunlu dersler için genel olarak iletişim bilimleri ve yeni medyaya özgü dersler alanında yoğunlaştığı, seçmeli derslerde ise halkla ilişkiler ve reklamcılık, tasarım, fotoğraf, video, sinema gibi derslerin oranlarında da artış olduğu gözlemlenmiştir. 
Araştırmanın ikinci bölümünde Kariyer.net adlı çevrimiçi iş arama platformu üzerinde Şubat-Mart 2019 boyunca "dijital medya uzmanı/müdürü" başlığı ile yayınlanmış olan altı adet iş ilanı bulunmuş ve bunlar içerik analizi yöntemi ile analiz edilmiş ve de istihdam edilecek bireylerde aranan niteliklere dair sektör beklentilerinin nicel bir değerlendirmesi sunulmuştur. İş ilanlarında kullanılan ifadeler ve hangi ilanda bu ifadelerin kullanıldığı Tablo 4'te sunulmuştur.

\begin{tabular}{|c|c|c|c|c|c|c|}
\hline Aranan Nitelikler / Bilgi ve Beceriler & $\begin{array}{l}\text { İlan } \\
1\end{array}$ & $\begin{array}{l}\text { İlan } \\
2\end{array}$ & $\begin{array}{l}\text { İlan } \\
3\end{array}$ & $\begin{array}{l}\text { İlan } \\
4\end{array}$ & $\begin{array}{l}\text { İlan } \\
5\end{array}$ & $\begin{array}{l}\text { İlan } \\
6\end{array}$ \\
\hline SEM & $\boldsymbol{v}$ & $\boldsymbol{v}$ & $\boldsymbol{v}$ & $\boldsymbol{v}$ & $\boldsymbol{v}$ & $\boldsymbol{v}$ \\
\hline SEO & $\checkmark$ & $\sqrt{v}$ & 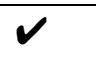 & $\checkmark$ & $\checkmark$ & $\checkmark$ \\
\hline Sosyal medya reklamları & $\checkmark$ & $\checkmark$ & $\checkmark$ & $\checkmark$ & $\checkmark$ & $\checkmark$ \\
\hline Web Analytics & $\checkmark$ & $\checkmark$ & $v$ & $\checkmark$ & $\checkmark$ & $\checkmark$ \\
\hline İçerik Üretebilen (metin, fotoğraf, video vb.) & & & $\boldsymbol{v}$ & $\boldsymbol{v}$ & & \\
\hline $\begin{array}{l}\text { Dijital medya dünyasındaki trendleri takip } \\
\text { edebilen }\end{array}$ & & $\checkmark$ & $\checkmark$ & $\boldsymbol{V}$ & $\checkmark$ & $\checkmark$ \\
\hline Sosyal medya hesaplarının yönetimi & $\checkmark$ & $\checkmark$ & $\checkmark$ & 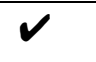 & $\checkmark$ & $\checkmark$ \\
\hline $\begin{array}{l}\text { Sosyal medya üzerinden müşteri ilişkileri } \\
\text { yönetimi }\end{array}$ & $\checkmark$ & $\checkmark$ & $\checkmark$ & $\checkmark$ & $\checkmark$ & $\checkmark$ \\
\hline Yaratıcı proje gelişme becerisi & $\boldsymbol{v}$ & $\boldsymbol{v}$ & $\boldsymbol{v}$ & & & $\boldsymbol{v}$ \\
\hline Dijital medya planlamasına hâkim & $\checkmark$ & $\checkmark$ & $\checkmark$ & $\boldsymbol{V}$ & $\checkmark$ & $\checkmark$ \\
\hline Dijital medya bütçe yönetimine hâkim & $\boldsymbol{v}$ & & $\boldsymbol{v}$ & & & \\
\hline İyi derecede İngilizce & $\checkmark$ & $\checkmark$ & & $\boldsymbol{V}$ & & $\checkmark$ \\
\hline En az 1 yıl tecrübe & $\checkmark$ & $\boldsymbol{v}$ & $\boldsymbol{V}$ & $\boldsymbol{v}$ & $\boldsymbol{v}$ & $\boldsymbol{v}$ \\
\hline
\end{tabular}

Tablo 4: Örnekleme dahil edilen iş ilanlarında "Dijital Medya Uzmanı" olarak aranan bireylerin sahip olması beklenen nitelikler, bilgi ve beceriler.

Yukarıdaki tabloda en dikkat çekici durum, sıralanan bütün niteliklerin tek bir bireyde aranıyor olmasıdır. Tabloda belirtilen bütün nitelikler, her biri farklı bilgi ve beceriler gerektiren ayrı uzmanlık alanlarıdır. Bu niteliklerin tek bir bireyde aranıyor olması, yeni medyanın belirli bir alanında uzmanlaşmaya olanak vermeyen bir durumu ortaya koymaktadır. Örneğin "sosyal medya reklamları" başlığı çok genel bir ifadedir. Günümüzde onlarca sosyal medya platformu olduğunu göz önünde bulundurduğumuzda, bir bireyin tüm bu farklı mecralar için reklam içeriği üretmesi, yönetmesi, müşteri ilişkilerini yürütmesi, planlama ve bütçe yapması başlı başına bir iştir. Bunlara ek olarak söz konusu bireyin, aynı zamanda, yine birbirinden farklı olan 
SEO (Search Engine Optimization-Arama Motoru Optimizasyonu) ve SEM (Search Engine Marketing- Arama Motoru Reklamcılığı) işlerini de yapması beklenmektedir. Her ne kadar ilanlarda yer alan ifadeler, yaratıc endüstriler bölümünde belirtilen kavram ve özelliklerle örtüşse de, alanda uzmanlaşmak konusunda bir sorun olduğu görülmektedir.

\section{Sonuç}

$\mathrm{Bu}$ araştırmada, yaratıcı endüstrilerin bir alanı olan yeni medyada, yükseköğretim müfredatlarındaki eğilimlerle sektör beklentilerinin bir göstergesi olarak kabul edilen iş ilanlarındaki eğilimlerin ne kadar örtüştüğü değerlendirilmiştir.

Araştırma örneklemine dahil edilen üniversitelerdeki müfredat analizi sonucunda, üniversitelerin zorunlu derslerde iletişim bilimleri ve yeni medyaya özgü dersler vermeyi tercih ettikleri, seçmeli derslerde ise yine yeni medyaya özgü derslerin yanında, zorunlu derslere kıyasla daha fazla oranlarda halkla ilişkiler ve reklamcilık ile tasarım dersi sundukları bulunmuştur.

İş ilanlarına göre dijital medya uzmanı olarak istihdam edilecek bireylerde aranan özellikler, büyük oranda halkla ilişkiler ve reklamcılık alanıyla ilişkilidir. Ayrıca adayların tasarım, fotoğraf, metin yazımı gibi konulara da hâkim olması beklenmektedir. Müfredat analizinde örnekleme dahil edilen üniversitelerde bu alanlarda ders verildiği görülmektedir. Ek olarak, iş ilanlarında adayların medya planlama ve bütçe konularına da hâkim olması beklenmektedir. Ancak örnekleme dahil edilen üniversitelerden sadece üç bölümde medya planlama dersi olduğu görülmüştür. Nişantaşı Üniversitesi, Türkçe Yeni Medya Bölümü'nde seçmeli, İngilizce bölümde ise zorunlu ders olarak ve İstanbul Şehir Üniversitesi'nde de zorunlu ders olarak vardır. Diğer üniversitelerde bu ders yer almamaktadır. Müfredat geliştirme çalışmalarında bu konunun dikkate alınmasında fayda vardır.

İş ilanlarında aranan diğer iki önemli nitelik ise, SEO ve SEM konusunda bilgi ve beceri sahibi olunmasıdır. Müfredat analizinde, adında bu ifadelerin geçtiği hiçbir derse rastlanmamış olmasına karşın, yeni medya uygulamaları gibi ifadeler içeren derslerin içinde bu konuların ele alınyor olma ihtimali göz önünde bulundurulmalıdır. Ancak yine de müfredatlarda bu isimlerle ders olmaması nedeniyle bu konulara yeterince önem verilmediği varsayılabilir. Zira SEO ve SEM konuları öğrencilere uygulamalar üzerinden gösterilerek öğretildiği takdirde ayrı bir ders olarak işlenecek kadar yoğun, kapsamlı içeriğe sahiptir. $\mathrm{Bu}$ nedenlerle müfredatların bu anlamda değerlendirilmesi faydalı olacaktır. 
Benzer şekilde, müfredat analizinde hiçbir üniversitede "yaratıcı endüstriler" veya benzeri bir isimde ders olmadığı da görülmüştür. Bu çalışmanın yaratıcı endüstriler bölümünde ifade edildiği gibi, yaratıcı endüstrilerin bir parçası olan yeni medyada, konunun ayrı bir ders olarak ele alınması, konuyla ilgili farkındalık yaratılması anlamında faydalı olacaktır. Ek olarak, Türkiye raporları dikkate alındı̆̆ında, fon bulma, proje geliştirme gibi noktaların da derslerde işlenmesi alana katkı sağlayacaktır.

Ayrıca, daha önce ifade edildiği gibi, İngilizce kökenli "digital" kelimesi birebir çeviride "sayısal" anlamına gelmektedir ve bu nedenle öz Türkçe olarak "sayısal medya" kullanılmaktadır. Bu bağlamda dijital (sayısal) medya için iş ilanlarındaki niteliklerden bazıları doğası gereği bilişim ve matematik bilgisi gerektirmektedir. Örnekleme dahil edilen tüm bölümler, 2018 YÖK Atlasına göre sözel puanla öğrenci kabul etmektedir. Müfredat analizinde tüm zorunlu ve bölüm/fakülte seçmeli dersler arasında istatistik vb. gibi herhangi bir sayısal derse rastlanmamıştır. İncelenen üniversitelerden bazıları üniversite seçimlik ders seçeneği de sunmaktadır, ancak bu çalışma kapsamındaki araştırmada bu dersler tabloya dahil edilmemiştir. İş ilanlarında yer alan SEO, SEM ve medya planlama, bütçe alanları da belirli oranda matematik bilgisi gerekmektedir. Tüm bunlar göz önüne alındığında yükseköğretimde yeni medya bölümlerinde müfredat geliştirme çalışmalarında sayısallaşma adına bazı adımlar atılmasının ve çalışmalar sonucunda ihtiyaç duyulması halinde sözel yerine eşit ağırlıklı puanla öğrenci seçiminin yapılmasının faydalı olacă̆ına inanılmaktadır.

İş ilanlarının analizinde, adayların medyanın farklı alanlarına hâkim olan niteliklere sahip olmasının beklendiği görülmektedir. Müfredat analizinde de yine medyanın farklı alanlarını kapsayan derslerde eğitim verildiği görülmüştür. Ancak medyanın birçok alanı yerine belirli bir alanında uzmanlaşmak, sektörde daha nitelikli işlerin üretilmesini sağlayacaktır. Bu bağlamda hem yaratıcı işgücü yetiştirmeyi hedefleyen üniversitelerin belirli bir ekol oluşturup buna göre yeni medyanın belirli bir alanında daha yoğun eğitim vermeye odaklanması, hem de sektörün uzmanlaşma yönünde bir eğilim göstermesinin tüm paydaşlar için daha faydalı olacağına inanılmaktadır. Ancak bu noktada, yükseköğretimin esas hedefinin sektörle ilgili gelişmeleri de takip ederek alanla ilgili eleştirel, bilimsel bilgi üretmek olduğu da göz ardi edilmemelidir.

Doküman inceleme ve içerik analizi yöntemlerini kullanarak nicel bir değerlendirme yapma hedefindeki bu çalışmanın, müfredatlarda yer alan derslerde, ideal olarak kazandırılması gereken bilgi ve becerilerin kazandırılıp kazandırılmadığını ve bunların sektör beklentilerini karşılayıp karşılamadığını derinlemesine 
değerlendirebilmek için nitel analizler içeren başka çalışmalarla desteklenmesinin alana katkı yapacağına inanılmaktadır.

\section{Kaynaklar}

Akdağ, M. ve Akgül, M. (2017). Türkiye'de yeni medya eğitimi üzerine niceliksel bir betimleme. Erciyes İletişim Dergisi, 5 (1), 210-220.

Aslan, P. (2018). Bir uluslararası halkla ilişkiler stratejisi olarak kültür ve yaratıcı endüstri ürünleri: Latin Amerika pazarında Türk dizileri üzerine bir araştırma. (Yayımlanmamış doktora tezi). Danışman: Prof. Dr. Yıldız Dilek Ertürk. İstanbul Üniversitesi, Sosyal Bilimler Enstitüsü, Halkla İlişkiler Ana Bilim Dalı Doktora Programı.

Aslan, C. E. (2017). Türkiye'de iletişim eğitiminin başlangıcı: Uluslararası etkiler açısından bir değerlendirme. (Yayımlanmamış yüksek lisans tezi). Danışman: Doç. Dr. Burcu Sümer. Ankara Üniversitesi, Sosyal Bilimler Enstitüsü, Radyo, Televizyon ve Sinema Ana Bilim Dalı Yüksek Lisans Programı.

Aslan, H. (2009). Medya okuryazarlğ̆ının görsel kültür ve sanat eğitimi ekseninde çözümlenmesi. (Yayımlanmamış yüksek lisans tezi). Danışman: Doç Dr. Metin Eker. Ondokuz Mayıs Üniversitesi, Sosyal Bilimler Enstitüsü, Güzel Sanatlar Eğitimi Ana Bilim Dalı, Güzel Sanatlar Eğitimi Yüksek Lisans Programı.

Ashton, D. ve Noonan, C. (2013). Cultural work and higher education, Londra: Palgrave Macmillan.

Bakan, U. (2010). İlköğretim media okuryazarlı̆̆ı dersinin öğrencilerin eleştirel düşünme becerilerine etkisi. (Yayımlanmamış yüksek lisans tezi). Danışman: Doç. Dr. Hüseyin Köse. Atatürk Üniversitesi, Sosyal Bilimler Enstitüsü, Gazetecilik Ana Bilim Dalı Yüksek Lisans Programı.

Ball, L., Pollard, E., Stanley, N. (2010). Creative graduates creative futures. Institute for Employment Studies. Erişim: 12 Nisan 2019,

https://www.employment-studies.co.uk/sites/default/files/471sum.pdf

Binark, M. (Der.), (2007). Yeni medya çalışmaları. Ankara: Dipnot.

BOP Consulting (2010). Mapping the creative industries: A toolkit. Creative and Cultural Economy. London: British Council. Erişim: 12 Nisan 2019.

https://creativeconomy.britishcouncil.org/media/uploads/files/English_mapping_t he_creative_industries_a_toolkit_2-2.pdf 
Bridgstock, R. (2016). Educating for digital futures: what the learning strategies of digital media professionals can teach higher education. Innovations in Educatin and Teaching International. 53 (3), 306-315. Erişim: 12 Nisan 2019

http://dx.doi.org/10.1080/14703297.2014.956779.

Buckingham, D. (2007). Media education goes digital: An introduction. Learning, Media and Technology, 32 (2), 111-119. doi: 10.1080/17439880701343006.

Can, S. (2017). İletişim eğitiminde akademi ve sektör beklentileri üzerine bir araştırma. (Yayımlanmamış doktora tezi). Danışman: Prof. Dr. Mehmet Sezai Türk. Erciyes Üniversitesi, Sosyal Bilimler Enstitüsü, Halkla İlişkiler ve Tanıtım Ana Bilim Dalı, Halkla İlişkiler Doktora Programı.

Creative Skillset (2010), Strategic skills assessment for the Cceative media industry. Erişim: 12 Nisan 2019.

https://www.screenskills.com/media/1522/skillset_strategic_skills_assessment_for _the_creative_media_industries_in_the_uk_2010.pdf

Cultural Times (2015). The first global map of cultural and creative industries.Erişim: 1 Nisan 2019.

https://en.unesco.org/creativity/sites/creativity/files/cultural_times._the_first_global_ma p_of_cultural_and_creative_industries.pdf

Demir, M.E. (2014). Yaratıc Endüstriler. ILEF Dergisi, 87-107.

Demir, M.E. (2018). Türkiye'de Yaratıcı Emek. Moment Dergi, 5(2), 174-194.

Deng, L., Ma, W.W.K., Fong, C.W.R. (Der.), (2018) New media for educational change. Selected Papers from HKAECT 2018 International Conference. Singapore: Springer.

Dumlu, A. (2018). Katılımcı yurttaşlık bilincinin geliştirilmesi bağlamında AB ülkelerinde media okuryazarlı̆̆ı. (Yayımlanmamış yüksek lisans tezi). Danışman: Dr. Öğr. Üye. Sibel Karaduman. Akdeniz Üniversitesi, Sosyal Bilimler Enstitüsü, Radyo, Televizyon ve Sinema Ana Bilim Dalı Yüksek Lisans Programı.

Dutton, W. H., Loader, B. D. (Der.), (2002). Digital Acedeme - The new media and institutions of higher education and learning. Londra: Routledge.

Ekşioğulları, M. (2018). Medya okuryazarlı̆̆ı eğitim ve uygulamalarının eleştirel bağlamda, Kanada, Almanya, Norveç'in Türkiye ile değerlendirilmesi. (Yayımlanmamış yüksek lisans tezi). Danışman: Yrd. Doç. Dr. Kerim Karagöz. Kocaeli Üniversitesi, Sosyal Bilimler Enstitüsü, İletişim Tasarım Ana Bilim Dalı Yüksek Lisans Programı.

Erstad, O., Gilje, O., de Lange, T. (2007). Re-mixing multimodal resources: multiliteracies and digital productiojn in Norwegian media education. Learning, Media and Technology, 32 (2), 183-198. doi: 10.1080/17439880701343394. 
Federov, A. (2014). Media education: Opinions of Russion teachers. European Researcher, 87 (11-2), 2022-2034. doi: 10.13187/er.2014.87.2022.

Fleischmann, K. ve Daniel, R. J. (2010). Increasing authenticity through multidisciplinary collaboration in real-life scenarios in digital media design education. CoDesign, 6 (2), 61-74. doi: 10.1080/15710882.2010.493940

Flew, T. (2014). New media: An introduction. Oxford: Oxford University Press.

Güven, B. (2017). Yaratıcı endüstrilerde eğitim ve işgücü ilişkisi: İstanbul çalışması. (Yayımlanmamış yüksek lisans tezi). Danışman: Doç. Dr. Ebru Kerimoğlu. İstanbul Teknik Üniversitesi, Fen Bilimleri Enstitüsü, Şehir ve Bölge Planlama Ana Bilim Dalı, Bölge Planlama Yüksek Lisans Programı.

Horkheimer, M. ve Adorno, T. W. (1995). Aydınlanmanın diyalektiği - Felsefi fragmanlar III. (Oğuz Özügül, Çev.) İstanbul: Kabalcı.

İnan, T. (2010). Öğretmen adaylarının media okuryazarlık düzeyleri ve media okuryazarlı̆̆ına ilişkin görü̧sleri. (Yayımlanmamış yüksek lisans tezi). Danışman: Yrd. Doç. Dr. Turan Temur. Dumlupınar Üniversitesi, Sosyal Bilimler Enstitüsü, İlköğretim Ana Bilim Dalı, Sosyal Bilgiler Öğretmenliği Yüksek Lisans Programı.

Jenkins, H. (2006). Convergence Culture: Where old and New Media Collide. New York University Press.

Kerimoğlu, E., Güven-Güney, B. (2018). İstanbul'da Yaratıcı İşgücünün Eğitimi ve Endüstri Pratikleri Üzerine Bir Değerlendirme. Sosyoekonomi. Vol.26(37). Pp.57-80. Doi: 10.17233.

Koç, E. (2016). Türkiye'deki media okuryazarlı̆̆ı için bir uygulama önerisi. (Yayımlanmamış doktora tezi). Danışman: Prof. Dr. Şahin Karasar. Maltepe Üniversitesi, Sosyal Bilimler Enstitüsü, İletişim Bilimleri Ana Bilim Dalı, İletişim Bilimleri Doktora Programi.

Kutlu, M. (2018). Medya okuryazarlğ̆ uygulamalardaki aksaklıklar: Kayseri örneği. (Yayımlanmamış yüksek lisans tezi). Danışman: Dr. Öğr. Üye. Onur Önürmen. Erciyes Üniversitesi, Sosyal Bilimler Enstitüsü, Radyo, Televizyon ve Sinema Ana Bilim Dalı Yüksek Lisans Programı.

Manovich, L. (2002). The Language of New Media. Cambridge: MIT Press.

Park, H. W., Biddix ve J. P. (2008). Digital media education for Korean youth. The International Information \& Library Review, 40, 104-111. doi: 10.1016/j.iilr.2007.12.003.

Peppler, K. ve Kafai, Y. (2007). From SuperGoo to Scratch: Exploring creative digital media production in informal learning. Learning, Media and Technology, 32 (2), 149166. doi: 10.1080/17439880701343337. 
Seylan, S. (2008). Medya okuryazarlığı ders uygulamalarında dünya üzerinde görülen aksaklıklar. (Yayımlanmamış yüksek lisans tezi). Danışman: Prof. Dr. Şermin Tekinalp. İstanbul Kültür Üniversitesi, Sosyal Bilimler Enstitüsü, İletişim Sanatları Ana Bilim Dalı, İletişim Sanatları Yüksek Lisans Programı.

Sweeny, R. W. (2015). Dysfunction and decentralization in new media art and education. Bristol: Intellect Ltd.

Şimşek, H. S. (2018). Yaratıcı endüstri bağlamında televizyon filmi senaryoları: Saruhan ve Pinhan örneği. (Yayımlanmamış yüksek lisans tezi). Danışman: Prof. Dr. Celal Oktay Yalın. Maltepe Üniversitesi, Sosyal Bilimler Enstitüsü, Radyo, Televizyon ve Sinema Ana Bilim Dalı Yüksek Lisans Programı.

Terranova, T. (2004). Network culture: Politics for the information age, Londra: Pluto Press.

Tokgöz, O. (2003). Türkiye'de iletişim eğitimi: Elli yıllık bir geçmişin değerlendirilmesi", Kültür ve Iletişim, 6(1), Kış, 9-32.

UNCTAD (2010). Creative Economy Report, 10 Nisan 2019. https://unctad.org/en/docs/ditctab20103_en.pdf

van Dijk, J. (2004). Digital Media. John D. H. Downing, Denis McQuail, Philip Schlesinger ve Ellen Wartella (Der.), içinde The Sage Handbook of Media Studies (s.145-163). Londra: Sage.

YEKON (2014), Istanbul Yaratıcı Ekonomi Çalışmaları Atölyesi Final Raporu, Istanbul Bilgi Universitesi Kültür Politikaları ve Yönetimi (KPY) Araştırma Merkezi. Erişim 10 Nisan 2019. http://www.yekon.org/public/yaratici-ekonomi-atolyesi-raporu.pdf

Yengin, D. A. (2017). Türkiye'de iletişim fakültelerinde halkla ilişkiler eğitimi ve sorunları. (Yayımlanmamış doktora tezi). Danışman: Prof. Dr. Emine Özden Çankaya. İstanbul Aydın Üniversitesi, Sosyal Bilimler Enstitüsü, Halkla İlişkiler ve Tanıtım Ana Bilim Dalı, Halkla İlişkiler ve Tanıtım Doktora Programı.

Yeni Medya Çalışmaları Ulusal Kongre. www.yenimedya.org.tr

Yıldız, V. A. (2011). Bir sosyal öğrenme aracı olarak media ve ahlaki gelişim kuramları açısından media okuryazarlı̆̆ına eleştirel bir bakış. (Yayımlanmamış yüksek lisans tezi). Danışman: Yrd. Doç. Dr. A. Halim Ulaş. Atatürk Üniversitesi, Eğitim Bilimleri Enstitüsü, İlköğretim Ana Bilim Dalı, Sınıf Öğretmenliği Yüksek Lisans Programı. YÖK Lisans Atlası. Erişim 15.03.2019. https://yokatlas.yok.gov.tr/lisans-anasayfa.php 


\section{Üniversite müfredatları:}

Bahçeşehir Üniversitesi, Yeni Medya Lisans Programı. Erişim: 10 Mart 2019.

https://bau.edu.tr/icerik/2409-yeni-medya-lisans-programi

Beykent Üniversitesi, Yeni Medya Bölümü. Erişim: 12 Nisan 2019.

https://if.beykent.edu.tr/bolumler/yeni-medya/ders-plani-ve-yapisi

İstanbul Gelişim Üniversitesi, Yeni Medya Bölümü. Erişim: 10 Mart 2019.

https://iisbf.gelisim.edu.tr/bolum/yeni-medya-145/mufredat

İstanbul Okan Üniversitesi, Yeni Medya Bölümü. Erişim: 10 Mart 2019.

https://www.okan.edu.tr/ubf/sayfa/4954/ders-programi-11/

İstinye Üniversitesi, Yeni Medya Bölümü. Erişim: 10 Mart 2019.

https://iisbf.istinye.edu.tr/tr/bolumler/yeni-medya/ders-plani

Kadir Has Üniversitesi, Yeni Medya Bölümü. Erişim: 10 Mart 2019.

https://bologna.khas.edu.tr/program/50000724/ders-plani-sap

Kadir Has Üniversitesi, Yeni Medya Bölümü. Neden Yeni Medya. Erişim: 12 Nisan

2019. http://www.khas.edu.tr/3009/neden-yeni-medya

Nişantaşı Üniversitesi, Yeni Medya Bölümü (Türkçe). Erişim: 10 Mart 2019.

http://bologna.nisantasi.edu.tr/Home/DetailPrograms/27

Nişantaş1 Üniversitesi, Yeni Medya Bölümü (İngilizce). Erişim: 10 Mart 2019.

http://bologna.nisantasi.edu.tr/Home/DetailPrograms/28

Uşak Üniversitesi, Yeni Medya Bölümü. Erişim: 10 Mart 2019.

https://iletisim.usak.edu.tr/upload/iletisim/F9SqdWmmru_Yeni\%20Medya\%20B\%

C3\%B61\%C3\%BCm\%C3\%BC-\%202018\%20M\%C3\%BCfredat\%C4\%B1.pdf

İstanbul Arel Üniversitesi, Yeni Medya ve İletişim Bölümü. Erişim: 10 Mart 2019.

https://www.arel.edu.tr/iletisim-fakultesi/yeni-medya-ve-iletisim-bolumu/dersler

İstanbul Aydın Üniversitesi, Yeni Medya ve İletişim Bölümü. Erişim: 10 Mart 2019.

https://ebs.aydin.edu.tr/index.iau?Page=BolumDersleri\&BK=1011\&DersTuru=0\&ln $=\operatorname{tr}$

İstanbul Kültür Üniversitesi, Yeni Medya ve İletişim Bölümü. Erişim: 10 Mart 2019. https://legacy.iku.edu.tr/TR/ects_bolum.php? $\mathrm{m}=1 \& \mathrm{p}=125 \& \mathrm{f}=5 \& \mathrm{r}=0$ \&ects=ders

İstanbul Medipol Üniversitesi, Yeni Medya ve İletişim Bölümü. Erişim: 10 Mart 2019. https://mebis.medipol.edu.tr/programbilgi/program/10196

İstanbul Şehir Üniversitesi, Yeni Medya ve İletişim Bölümü. Erişim: 10 Mart 2019. https://www.sehir.edu.tr/tr/akademik/iletisim-fakultesi/yeni-medya-veiletisim/ders-plani 
İş İlanları: Erişim 17 Mart 2019.

İlan 1: https://www.kariyer.net/is-ilani/migros-ticaret-a-s-dijital-medya-uzmani-2100242 İlan 2: https://www.kariyer.net/is-ilani/gizli-firma-dijital-medya-operasyon-uzmani2254808

İlan 3: https://www.kariyer.net/is-ilani/tan-alize-kozmetik-ve-temizlik-urun-san-ve-tica-s-dijital-medya-muduru-2223605

İlan 4: https://www.kariyer.net/is-ilani/implant-akademi-dijital-medya-uzmani-2264593

İlan 5: https://www.kariyer.net/is-ilani/integral-entegre-yapi-teknolojileri-san-ve-tic-1dijital-medya-uzmani-2191418

İlan 6: https://www.kariyer.net/is-ilani/kar-otomotiv-ve-servis-hizmetleri-sanayi-ticaret1-dijital-pazarlama-ve-sosyal-medya-uzmani-2248752 